OECD Economics Department Working Papers No. 304

The Width of the IntraEuropean Economic Borders

\author{
Alain de Serres, \\ Peter Hoeller, \\ Christine de la \\ Maisonneuve
}


THE WIDTH OF THE INTRA-EUROPEAN ECONOMIC BORDERS

ECONOMICS DEPARTMENT WORKING PAPERS NO. 304

by

Alain de Serres, Peter Hoeller and Christine de la Maisonneuve

Most Economics Department Working Papers, beginning with No. 144, are now available through OECD's Internet Web site at http://www.oecd.org/eco/eco 


\begin{abstract}
RÉSUMÉ
This paper first provides a brief overview of the literature on market segmentation and then presents an empirical exercise that sheds more light on the significance of border effects across European countries. The literature suggests that integration in the EU goods and financial markets is typically more advanced than among the other OECD countries. On the other hand, integration in Europe remains significantly lower than that observed between regions within countries. The empirical exercise is based on a set of comparable price data of tradeable goods collected just before the launch of the single currency. The paper finds that for a given distance, crossing national borders adds significantly to the price differential across European cities. However, this border effect is substantially smaller than the one found in previous estimates focusing on European and North American cities, which were based on the comparison of much broader price indices such as the consumer price index.
\end{abstract}

JEL Code: E32, F14, F15

Keywords: European Union, economic integration, border effect.

$* * * * * * * * * * * * *$

Cette étude passe brièvement en revue la littérature traitant de la segmentation des marchés puis présente un exercice empirique qui examine la question de l'importance des effets frontière à travers les pays européens. Dans l'ensemble, les conclusions des diverses études portant sur la question semblent indiquer que l'intégration des marchés de biens et des marchés financiers européens est plus avancée qu'elle ne l'est généralement parmi les autres pays de l'OCDE. Par contre, l'intégration des marchés en Europe demeure sensiblement plus faible que celle observée entre les régions d'un même pays. L'exercice empirique présenté dans cette étude s'appuie sur un ensemble de données comparables de prix de biens échangeables recueillis dans un grand nombre de villes européennes à la veille du lancement de la monnaie unique. Les résultats obtenus mettent en évidence que pour une distance donnée, le fait de traverser les frontières nationales ajoute sensiblement à la différence de prix entre villes européennes. Cependant, cet effet frontière est largement inférieur à celui rapporté dans certaines études antérieures appliquées au cas des villes européennes et nord-américaines mais dont les estimations ont été obtenues sur la base d'indices de prix agrégés, en l'occurrence des indices de prix à la consommation.

Classification JEL : E32, F14, F15

Mots-clés : Union européenne, intégration économique, effet frontière. 


\section{TABLE OF CONTENTS}

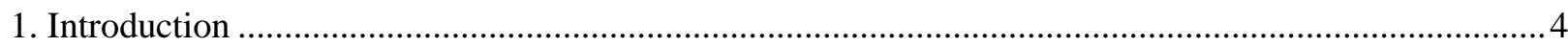

2. Empirical evidence on the degree of market integration within and across countries...........................5

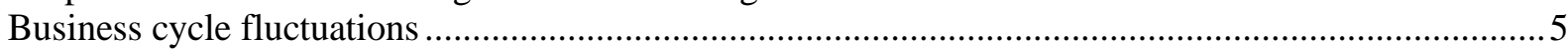

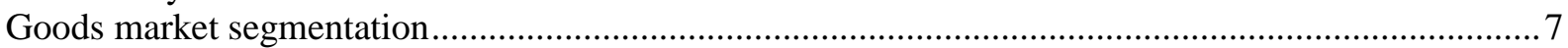

3. Remaining price dispersion within and across European countries ............................................... 11

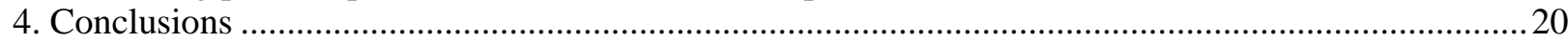

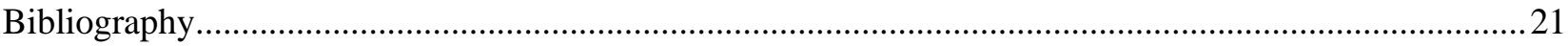

\section{Boxes}

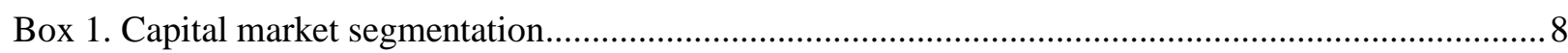

\section{Tables}

1. Cross-country consumption and output growth correlations .................................... 6

2. Consumption and output growth correlations across Canadian provinces ........................ 9

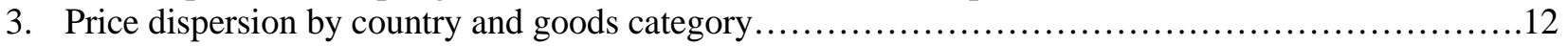

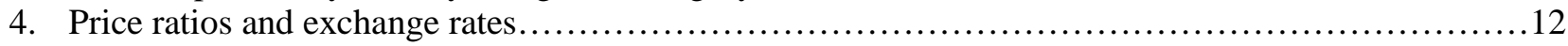

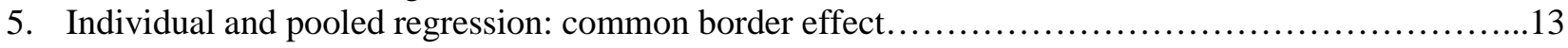

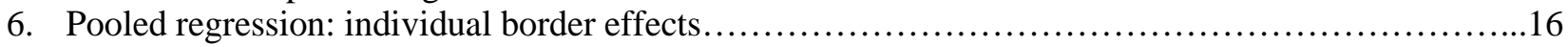

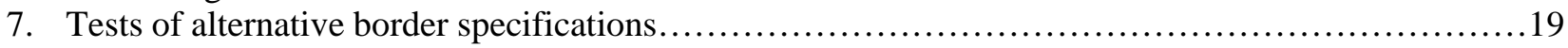

Figure

1. Average commodity prices...................................................................... 


\title{
THE WIDTH OF THE INTRA-EUROPEAN ECONOMIC BORDERS
}

\author{
Alain de Serres, Peter Hoeller and Christine de la Maisonneuve ${ }^{1}$
}

\section{Introduction}

1. Over the past decades, economic integration in the European Union has proceeded swiftly in many dimensions, with the labour market being a notable exception. Closer integration lowers the vulnerability of countries to asymmetric shocks and broadens the channels for the transmission of shocks. Moreover, closer economic integration makes it easier for countries to support a common monetary policy stance. Previous OECD studies on Economic and Monetary Union (OECD, 1999 and 2000a) have documented various important channels that have promoted integration. Since 1970, for instance, the share of intra euro area trade in total trade has almost doubled and intra-industry trade flows - an indicator for industrial diversification - have risen sharply. At the same time, integration led to a lower dispersion of prices across countries, even though it remains fairly high and price convergence has progressed little in recent years. The single market programme has also had a sizeable impact on cross-border direct investment and merger activity. Progress in market integration has been uneven between countries and markets, however. Some markets, like telecommunications or energy are only in the process of being opened to greater competition, implementation of the single market in public procurement has not advanced much and the mergers in banking mostly take place within domestic markets rather than across borders.

2. Many policy-imposed barriers on the flow of goods, capital and labour have disappeared. However, some changes are fairly recent, including the introduction of the euro so that national borders have not yet lost all their significance. In addition, much fewer policies are centralised in the European Union as compared to federations and market segmentation is also influenced by language and cultural differences. A better understanding of how economies will evolve as national borders become less important can be gained by analysing the interactions between regions within a country. They provide a natural benchmark for understanding economic relationships in integrated areas. They can reveal important implications of integration for trade, growth, business cycles or capital flows. They can also be informative about the limitations to economic integration. Moreover, they can highlight differences in macro and microeconomic policy effects that influence segmentation and the propagation of macroeconomic policy. The literature has focused mainly on capital, labour and goods market integration as well as business cycles in and across countries.

3. This paper sheds more light on the significance of the border effect across European countries using comparable price data for specific categories of manufactured goods collected in a large number of European cities. While the impact of national borders on price dispersion in Europe has been quantified in

1. The authors are all members of the Economics Department and were working on European issues when the work on this paper was carried out. They are indebted to Jørgen Elmeskov and Vincent Koen for their comments and suggestions. Special thanks go to Valerie Luccioni-Lassaut for the technical assistance in preparing this document. 
the past, it has generally been done on the basis of broad consumer price indices which may not be well suited for this type of exercise given their high level of aggregation and that European-wide harmonised CPIs have only become available recently. In contrast, this paper uses price data on dis-aggregated categories of goods that are relatively homogeneous and highly tradable. ${ }^{2}$ Based on this data sample, the paper finds that for a given distance, crossing a national border adds significantly to the price-level differential across European cities. However, this border effect is substantially lower than the one estimated in previous studies in the case of European cities (Engel and Roger, 2000a) or North American cities (Engel and Rogers, 1999, Rogers and Smith, 2001) on the basis of broader price indices.

4. Section 2 provides a brief overview of the empirical literature on market integration, focusing on business cycles as well as capital and goods market. It draws mainly on the empirical research concerning the United States and Canada, where a large body of literature is available, but also on the more limited amount of evidence concerning Europe. The bulk of evidence suggests that cross-border goods and financial market integration is typically more advanced in the European Union than between other OECD countries as indicated, inter alia, by the finding of stronger correlations of consumption and output growth rates among these countries. On the other hand, the degree of market integration between EU countries still remains significantly lower than that observed between regions within individual countries even though the literature shows considerable disagreement about the remaining impact of national borders (the border effect) on market segmentation. The review is followed, in section 3, by the empirical exercise focusing on the degree of price dispersion prevailing both within and across European countries on the eve of the launch of the euro. The main findings are summarised in section 4.

\section{Empirical evidence on the degree of market integration within and across countries}

\section{Business cycle fluctuations}

5. Evidence on the sources of business cycle fluctuations in and across countries has been used to highlight the degree of market segmentation. Cyclical developments are usually investigated by decomposing output or employment fluctuations into industry and regional components and a common national or additional common international component. Clark and Shin (1998) review a large number of studies. They tend to show that common shocks are of less importance in cross-country than in withincountry data. They also indicate that region-specific shocks account for a larger share of variation in international data than in within-country data. Finally, industry-specific shocks are less important internationally than within the United States. Not all studies find the same patterns, though. Forni and Reichlin (2001), for instance, come to the conclusion that European countries have a level of integration similar to that of the United States and that national shocks are not a sizeable source of fluctuations. Moreover, a core of the most integrated regions in Europe appears not to be affected by national boundaries.

6. Overall, Clark and Shin conclude that a lowering of the economic borders dividing nations should reduce the importance of country-specific shocks, while common international and industry-

2. We are indebted to Stéphane Dochy from the Belgian Consumer Association for providing us with the price data set. 
Table 1. Cross-country consumption and output growth correlations ${ }^{1}$

(1981h1-2000h2)

\begin{tabular}{|c|c|c|c|c|c|c|c|c|c|c|c|c|c|c|c|c|c|c|}
\hline & Aut & Bel & Fin & Fra & Ger & Grc & Ire & Ita & Net & Prt & Spa & Euro & Gbr & Den & Swe & USA & Jpn & Can \\
\hline Austria & & 0.23 & 0.11 & 0.30 & 0.30 & 0.18 & 0.02 & 0.14 & 0.31 & 0.36 & 0.46 & 0.37 & 0.15 & -0.07 & -0.00 & -0.05 & 0.29 & -0.07 \\
\hline Belgium & 0.46 & & 0.17 & 0.58 & 0.55 & 0.63 & 0.31 & 0.75 & 0.60 & 0.55 & 0.78 & 0.83 & 0.18 & 0.08 & 0.50 & -0.03 & 0.29 & 0.16 \\
\hline Finland & 0.01 & 0.44 & & 0.50 & -0.27 & 0.32 & 0.13 & 0.44 & 0.03 & 0.02 & 0.36 & 0.20 & 0.62 & 0.08 & 0.57 & 0.42 & 0.14 & 0.38 \\
\hline France & 0.59 & 0.73 & 0.52 & & 0.24 & 0.46 & 0.08 & 0.55 & 0.29 & 0.54 & 0.65 & 0.55 & 0.31 & -0.13 & 0.54 & 0.05 & 0.21 & 0.06 \\
\hline Germany & 0.65 & 0.61 & -0.20 & 0.41 & & 0.06 & 0.17 & 0.44 & 0.56 & 0.40 & 0.54 & 0.49 & -0.03 & 0.00 & 0.20 & -0.13 & 0.32 & 0.05 \\
\hline Greece & 0.37 & 0.76 & 0.37 & 0.58 & 0.42 & & 0.19 & 0.55 & 0.22 & 0.17 & 0.47 & 0.43 & -0.11 & -0.14 & 0.20 & -0.21 & 0.25 & -0.05 \\
\hline Ireland & 0.17 & 0.57 & 0.48 & 0.37 & 0.14 & 0.44 & & 0.25 & 0.59 & 0.22 & 0.49 & 0.33 & 0.35 & 0.02 & 0.32 & 0.47 & -0.43 & 0.66 \\
\hline Italy & 0.44 & 0.77 & 0.45 & 0.71 & 0.53 & 0.58 & 0.25 & & 0.34 & 0.35 & 0.72 & 0.68 & 0.25 & 0.10 & 0.69 & 0.09 & 0.22 & 0.36 \\
\hline Netherlands & 0.59 & 0.67 & 0.27 & 0.43 & 0.63 & 0.60 & 0.51 & 0.55 & & 0.36 & 0.65 & 0.61 & 0.17 & 0.23 & 0.37 & 0.26 & -0.02 & 0.27 \\
\hline Portugal & 0.45 & 0.62 & 0.30 & 0.67 & 0.33 & 0.35 & 0.31 & 0.51 & 0.24 & & 0.64 & 0.57 & 0.24 & -0.23 & 0.32 & -0.26 & 0.11 & -0.06 \\
\hline Spain & 0.62 & 0.82 & 0.48 & 0.80 & 0.53 & 0.56 & 0.46 & 0.74 & 0.60 & 0.77 & & 0.86 & 0.42 & -0.17 & 0.64 & 0.14 & 0.22 & 0.35 \\
\hline Euro area & 0.70 & 0.87 & 0.26 & 0.71 & 0.55 & 0.65 & 0.38 & 0.76 & 0.70 & 0.60 & 0.83 & & 0.27 & -0.02 & 0.60 & 0.04 & 0.30 & 0.25 \\
\hline United Kingdom & 0.13 & 0.33 & 0.66 & 0.35 & -0.06 & 0.21 & 0.08 & 0.56 & 0.26 & 0.28 & 0.45 & 0.31 & & 0.15 & 0.46 & 0.67 & 0.15 & 0.67 \\
\hline Denmark & 0.08 & 0.21 & 0.28 & 0.12 & 0.05 & 0.36 & 0.05 & 0.34 & 0.23 & -0.18 & 0.12 & 0.18 & 0.45 & & 0.15 & 0.34 & -0.07 & 0.20 \\
\hline Sweden & 0.27 & 0.62 & 0.74 & 0.59 & 0.18 & 0.48 & 0.41 & 0.70 & 0.51 & 0.22 & 0.63 & 0.57 & 0.60 & 0.53 & & 0.35 & 0.06 & 0.44 \\
\hline United States & -0.03 & 0.37 & 0.47 & 0.17 & 0.13 & 0.34 & 0.27 & 0.46 & 0.58 & -0.11 & 0.24 & 0.31 & 0.50 & 0.27 & 0.53 & & -0.21 & 0.77 \\
\hline Japan & 0.26 & 0.30 & 0.02 & 0.30 & 0.41 & 0.13 & -0.18 & 0.41 & 0.04 & 0.44 & 0.33 & 0.41 & 0.09 & -0.15 & 0.04 & -0.08 & & -0.10 \\
\hline Canada & -0.05 & 0.42 & 0.55 & 0.24 & 0.05 & 0.36 & 0.29 & 0.55 & 0.46 & 0.04 & 0.30 & 0.33 & 0.59 & 0.29 & 0.62 & 0.88 & -0.03 & \\
\hline
\end{tabular}

1. The figures below the diagonal are output correlations and the figures above the diagonal are consumption correlations. The correlations of a euro area country's output or consumption growth with the eura area aggregate exclude that country's output and consumption from the aggregate.

Source: OECD. 
specific factors could gain in importance. That common factors could start to dominate in the euro area is supported by cross-country output growth correlations (Table 1), that indicate that the euro area's business cycle is more closely synchronised than that of the other countries. While closer integration of goods and factor markets are likely to be important in this context, the effects of monetary policy co-ordination in the European Union in the form of the Exchange Rate Mechanism and the Maastricht fiscal criteria should not be underestimated. However, if national macroeconomic policies have been important in synchronising business cycles, then the adoption of common policies, which limit the conduct of independent stabilisation policies may not alter much the importance of nation-specific shocks. If nation-specific shocks were to dominate, monetary union would not be desirable. So far, moving towards adopting common policies appears to have raised the common component in the euro area. This is also indicated by the rise in growth correlations over time, which are not reported.

\section{Goods market segmentation}

7. Research on goods markets has focused on differences in the size of intra-regional and international trade flows as well as price dispersion within and across countries. McCallum (1995), Helliwell (1996), Anderson and Smith (1999), and Wolf (2000), for instance, have found a surprisingly large border effect. After controlling for distance and other geographic variables (a dummy is used to distinguish between cross-border and internal trade flows), these studies show that trade between the Canadian provinces is from 10 to more than 20 times larger than between Canadian provinces and US States. ${ }^{3}$ In a study including the EU countries, Helliwell (1998) finds that being in the European Union reduces the size of such border effect from about 10 to 6.6 and sharing a common language cuts it further to 3.7. Nitsch (2000) also comes to the conclusion that the economic borders matter less in Europe than across the other OECD countries and demonstrates in addition that the border effect has declined over time. In contrast, Wei (1996) finds that the border effect is small across the OECD countries, close to a factor of only 2, and typically larger among EU countries than in the rest of the OECD. ${ }^{4}$ However, the results are strongly influenced by the approximate measures of intra-national distances and remoteness. ${ }^{5}$ There is clearly considerable disagreement as to the size of the border effect. ${ }^{6}$ Also capital markets appear to be more segmented internationally than at the national level (Box 1).

3. However, Anderson and van Wincoop (2001) showed that the high estimate obtained by McCallum resulted in large part from a mis-specification bias. They show that when the specification of the estimated equation is properly derived from the theoretical gravity model, the ratio of inter-provincial to provincestate trade is cut by half, from 20 to around 10. Although this remains substantial, the authors claim that it can be replicated with a reasonable parameterisation of the gravity model, and is much less of a puzzle considering the small size of the Canadian economy. For instance, trade between states is only 1.5 larger than province-to-state trade as a result of the border.

4. Also in Wei's study the home bias of the EU countries declines rapidly.

5. Helliwell (1998) argues that results for the OECD countries are at the lower end of the likely range. The studies on Canadian inter-provincial and Canada-US province-state trade should be more credible, because they rely on well-founded estimates of inter-provincial and province-state trade distances. On the other hand, Anderson and Smith (1999), after carefully examining and adjusting the trade data find a border effect that is less than half that originally estimated for US-Canadian trade.

6. Wolf also documents a sizeable intra-national home bias, with trade within US states being 3 times higher than across states. This suggests that home bias is unlikely to go away completely even when countries are highly integrated. 
ECO/WKP(2001)30

\section{Box 1. Capital market segmentation}

Despite the sharp rise of international capital flows, a large body of evidence shows that individuals hold too little of their wealth in foreign assets — the so-called home bias. Moreover, cross-country correlations of consumption are often even lower than cross-country output correlations, suggesting a low degree of risk sharing across countries. If countries experience different output shocks, output will have a low correlation across countries. Individuals, however, could buy claims on other countries' output, thereby reducing domestic income risk. In this case, consumption growth would have a high correlation, even when output growth rates do not.

Table 1 shows the output and consumption correlation matrix for the EU countries, the United States, Japan and Canada. A striking feature is that the correlations for both output and consumption are fairly high for the euro area countries and typically much lower for the other countries, indicating closer integration within the euro area than across the other OECD countries. While there is some tendency for consumption correlations to be lower than output correlations for the euro area countries, this is not uniformly so and differences are often not large. This contrasts with the results for the G-7 countries in 1950-92 reported in Lewis (1999), who finds lower correlations overall and bigger differences between output and consumption correlations. The same exercise for Canadian provinces shows that consumption growth correlations, indeed, tend to be high and much higher than output growth correlations (Table 2). It is striking that output growth correlations across provinces tend to be much lower than across the euro area countries, probably reflecting a much lower degree of industrial diversification.

A significant home bias can be explained by various factors (Lewis, 1999): home assets are a better hedge against country-specific risks; the tax, information and other costs of diversification exceed the gain; not all wealth (human capital being the largest item) and goods are tradeable; government restrictions impede investment in foreign assets. Some of these factors, such as government restrictions, have lost in importance over time, especially in the European Union. This could explain the reduced home bias in more recent data, especially for the euro area countries. Integration could go much further in the future. While there is no evidence for the degree of integration at the regional level in Europe, Crucini and Hess (2000) show for Canadian provinces, US states and Japanese prefectures that a much larger share of consumers pool risk across regions within a country than across countries. Also the correlation between saving and investment is lower within than across countries. While there is substantial evidence that international capital markets are more segmented than regional ones, the latter are not perfectly integrated. Overall, it appears that the degree of capital market integration between euro area countries lies somewhere in between.

8. In the absence of any barriers or costs to the movement of goods, price differences expressed in a common unit between comparable items in different locations would be quickly eroded. However, due to natural (transportation, information and other transactions costs) and administrative impediments (e.g. differences in local tax rates) prices generally differ within countries, let alone across borders where far more significant trade barriers usually prevail. Indeed, the failure of the law of one price to hold in cross-border trade has been well documented by various studies and continues to be substantiated by international surveys of prices. ${ }^{7}$ Focusing on Canadian provinces and US States, Engel and Rogers (1996 and 2000b) find again a border effect on the variance of relative prices (over time), which is very large as

7. See in particular Haskel and Wolf (2001) who find that the price of identical goods sold by the multinational retailer IKEA varies substantially across countries. They clearly reject the assumption that the law of one price holds for homogeneous, tradable goods. 
Table 2. Consumption and output growth correlations across Canadian Provinces

$(1982-1999)^{2}$

\begin{tabular}{|c|c|c|c|c|c|c|c|c|c|c|c|c|}
\hline & nfl & pei & ns & nb & que & ont & man & sask & alb & bc & yuk & nwt \\
\hline Newfoundland & & 0.72 & 0.85 & 0.81 & 0.83 & 0.94 & 0.71 & 0.62 & 0.54 & 0.53 & 0.56 & 0.14 \\
\hline Prince Edward Island & 0.35 & & 0.89 & 0.83 & 0.80 & 0.75 & 0.69 & 0.79 & 0.29 & 0.47 & 0.38 & 0.05 \\
\hline Nova Scotia & 0.43 & 0.06 & & 0.89 & 0.89 & 0.88 & 0.81 & 0.77 & 0.43 & 0.43 & 0.43 & -0.09 \\
\hline New Brunswick & 0.31 & 0.66 & 0.48 & & 0.84 & 0.83 & 0.60 & 0.60 & 0.33 & 0.46 & 0.40 & -0.02 \\
\hline Quebec & 0.55 & 0.20 & 0.42 & 0.25 & & 0.93 & 0.78 & 0.80 & 0.62 & 0.69 & 0.52 & -0.06 \\
\hline Ontario & 0.63 & 0.30 & 0.63 & 0.35 & 0.92 & & 0.73 & 0.75 & 0.65 & 0.63 & 0.46 & 0.00 \\
\hline Manitoba & 0.10 & -0.12 & 0.48 & -0.12 & 0.60 & 0.67 & & 0.78 & 0.51 & 0.42 & 0.60 & 0.13 \\
\hline Saskatchewan & -0.11 & -0.19 & -0.17 & -0.06 & 0.08 & -0.00 & 0.24 & & 0.51 & 0.38 & 0.23 & -0.03 \\
\hline Alberta & 0.19 & -0.24 & -0.01 & -0.42 & 0.53 & 0.46 & 0.46 & 0.03 & & 0.65 & 0.25 & 0.20 \\
\hline British Columbia & 0.17 & -0.02 & 0.00 & -0.04 & 0.62 & 0.50 & 0.38 & 0.09 & 0.72 & & 0.63 & 0.24 \\
\hline Yukon & -0.09 & -0.07 & 0.04 & 0.18 & 0.26 & 0.15 & 0.07 & 0.04 & -0.25 & 0.20 & & 0.30 \\
\hline North Western Territories & 0.18 & 0.11 & 0.21 & 0.05 & -0.43 & -0.23 & -0.37 & -0.43 & -0.23 & -0.47 & -0.43 & \\
\hline
\end{tabular}

1. The figures below the diagonal are output correlations and the figures above the diagonal are consumption correlations.

2. Except for North Western Territories, 1982-1998.

Source: Statistics Canada and OECD. 
compared to distance and by far too large to be explained by any remaining trade barriers. As with the empirical research on trade flows, distance captures again transport and information costs. ${ }^{8}$ While taking into account differences in costs (wages) across regions reduces the effect of distance on price variability, it does not affect the border effect. On the other hand, mark-ups appear to fluctuate widely with exchange rate changes and cross-border prices mainly move along with the exchange rate.

9. Using aggregate CPI data for 55 cities across 11 European countries, Engel and Rogers (2000a) estimated the importance of the border effect between European city pairs, based on the same econometric approach. Once again, they found a significant, albeit smaller, border effect on the variability of relative prices between cities. They also show that international relative price variability has declined over time between EU countries, though being initially much higher than intra-national price variability. ${ }^{9}$ In contrast to the original study on Canada and the United States, the multitude of currencies included in the sample of European cities allowed Engel and Rogers to go one step further and to test how much of the border effect could be accounted for by nominal exchange rate fluctuations. The results indicate that controlling for currency swings does indeed reduce substantially the size of the border coefficient, even though the latter still remains significant. ${ }^{10}$ This is taken as evidence that the deviations from the law of one price are largely explained by pricing-to-market strategies whereby prices set in local currencies are adjusted only gradually and infrequently, implying a very low exchange rate pass-through in the short term. For exporting firms, such pricing behaviour implies a high sensitivity of mark-ups to nominal exchange rate fluctuations, compensated, however, by lower menu $\operatorname{costs}^{11}$ and a reduced risk of facing permanent market share losses. In distinguishing between the two types of border effects, Engel and Rogers conclude that the stickiness of prices and volatility of exchange rates matter more than the "real" barriers highlighted in the aforementioned studies focusing on trade volumes. ${ }^{12}$

10. Besides pricing-to-market practices, significant price differences between similar items could also reflect the capacity by producers in some sectors to price discriminate across national markets, allowing them to capture a share of the consumer surplus. The latter can be substantial in the case of high value-added items, in particular when important differences in living standards lead to cross-market variations in the price elasticity of demand. Sizeable and persistent mark-up adjustments, for instance, seem to have a strong effect on car price differences across the EU countries (Goldberg and Verboven, 1998 and Annex V in OECD, 2001). However, such practices can only persist if there are trade barriers in the form of technical specifications or vertical integration combined with a lack of competition in the distribution system, which keep the market segmented even in the absence of tariffs and border controls. In

8. The fact that price convergence across borders is non-existent or only very slow has been researched extensively prior to the study by Engel and Rogers, without, however, investigating the border effect.

9. The decline in overall price dispersion in the European Union has been documented in other studies. One measure of dispersion, the coefficient of variation for the items included in Eurostat's Purchasing Power Parity exercise for all GDP components, has come down to 16 in 1996 and 14 when indirect taxes are excluded. This compares to a coefficient of variation of 11 across US cities in early 1998 (EC, 2000). Fresher albeit less comprehensive evidence suggests that, although some convergence took place between 1999 and 2000, price dispersion remains about twice as high across EU Member States as within them (Doyle, 2000).

10. In fact, controlling for exchange rate volatility reduces the size of their estimated border coefficient from 2.1 to 0.21 . Parsley and Wei (2000) also find that the border effect declines significantly when controlling for exchange rate variability and unit-shipping costs in a study of Japanese and US cities.

11. Menu costs are the costs of changing prices. They increase as the frequency of price adjustments rises.

12. After extending the original price study on Canadian and US cities to include Mexican cities, Rogers and Smith (2001) also reach the conclusion that the "nominal" border effect due to local price stickiness and exchange rate volatility is much stronger than the "real" border effect (though they are not mutually inconsistent). 
any case, the use of a broad CPI index to measure price dispersion may exaggerate the degree of price stickiness and the importance of the exchange rate channel if adjustments of individual goods prices are asynchronised and staggered over time (Blanchard, 1991). An additional drawback of using the CPI is that its composition has varied to quite some extent across countries, before standardised measures (the HICP) were produced in the European Union.

\section{Remaining price dispersion within and across European countries}

11. This section revisits the issue of price dispersion in Europe using more recent price information for specific categories of semi-durable, manufactured goods. It draws on a survey conducted in June 1998 for the European Consumers' Organisation, which provides comparable price data for 20 categories of goods across 39 European cities located in 11 countries, including one outside the European Union (Switzerland). Even though each goods category can include from 10 to 20 brands, the range of products covered in each town is sufficiently complete to ensure a relatively high degree of homogeneity. ${ }^{13}$ The approach is similar to that followed by Engel and Rogers, albeit with one important difference. Given that the survey provides a price comparison at one point in time only, the endogenous variable used in regression analysis is the percentage absolute difference in the price level (converted into ECU) of a particular good observed in city pairs. ${ }^{14}$ Hence, for each category the endogenous variable includes 741 price differential observations.

12. Table 3 presents the coefficient of variation of prices across cities within each country as well as for the entire sample of cities taken as a whole. A comparison of the last two columns suggests that although dispersion is generally higher across than within countries, it is the case neither for all countries, nor for all categories of goods. In particular, dispersion appears to be relatively high in Spain and Portugal, although this could be partly influenced by the smaller number of cities included in these countries. Not surprisingly, the average price level is found to be lowest in Portugal and Spain, whereas goods are most expensive in Switzerland and the United Kingdom (Figure 1). Besides the differences in living standards, the higher price in the latter two countries probably reflect in part the strength of their currencies, given that prices have been converted into a common currency (ECU). The average price ratios of these two countries are indeed considerably above the exchange rate (Table 4). For most other countries this ratio is very close to the exchange rate, but they are lower for Portugal and Spain, which is expected, given their lower per-capita income. The largest cross-country dispersions are found in the categories of watches, calculators, food processors and headphones. However, except for food processors, the dispersion in these categories is also relatively high within countries.

13. 18 of the 57 towns included in the original sample were excluded from the regression analysis due to their incomplete coverage of goods and, in some cases, because they were not sufficiently distant from other cities (less than 20 kilometres). Fortunately, most of these were located in countries (e.g. France and Belgium) which initially had a relatively large number of cities in the sample.

14. Engel and Rogers used instead the variance of the change over time of price level differences between city pairs.

15. Evidently, only a subset of these observations is truly independent. For instance, the predicted value of the price differential between Paris and Berlin could be implicitly derived from the predicted values of ParisRome and Rome-Berlin. That will differ from the predicted value for Paris-Berlin directly obtained from the equation and the difference will be reflected in the error term. 
Table 3. Price dispersion by country and goods category ${ }^{1}$

\begin{tabular}{|c|c|c|c|c|c|c|c|c|}
\hline \multicolumn{9}{|c|}{ June 1998} \\
\hline & Belgium & France & Italy & Netherlands & Portugal & Spain & $\begin{array}{c}\text { Average of } \\
\text { dispersion within } \\
\text { countries }^{2}\end{array}$ & Total $^{3}$ \\
\hline Car radios & 0.04 & 0.06 & 0.14 & 0.05 & 0.28 & 0.10 & 0.11 & 0.13 \\
\hline Walkmen / portable CD players & 0.12 & 0.06 & 0.10 & 0.09 & 0.08 & 0.22 & 0.11 & 0.12 \\
\hline Headphones & 0.20 & 0.22 & 0.39 & 0.15 & 0.42 & 0.28 & 0.28 & 0.27 \\
\hline Hi-fi systems & 0.05 & 0.09 & 0.12 & 0.04 & 0.08 & 0.05 & 0.07 & 0.14 \\
\hline Radio-cassette / CD players & 0.12 & 0.03 & 0.20 & 0.18 & 0.19 & 0.15 & 0.15 & 0.15 \\
\hline Video cameras & 0.10 & 0.15 & 0.08 & 0.11 & 0.10 & 0.04 & 0.10 & 0.22 \\
\hline Video tapes & 0.03 & 0.08 & 0.09 & 0.03 & 0.08 & 0.08 & 0.07 & 0.24 \\
\hline Video recorders & 0.05 & 0.06 & 0.04 & 0.02 & 0.07 & 0.08 & 0.05 & 0.07 \\
\hline Irons & 0.05 & 0.03 & 0.11 & 0.02 & 0.07 & 0.02 & 0.05 & 0.12 \\
\hline Food mixers / processors & 0.04 & 0.08 & 0.31 & 0.09 & 0.18 & 0.10 & 0.13 & 0.27 \\
\hline Electric razors & 0.06 & 0.04 & 0.09 & 0.08 & 0.06 & 0.07 & 0.07 & 0.17 \\
\hline Sport shoes & 0.04 & 0.06 & 0.07 & 0.05 & 0.13 & 0.08 & 0.07 & 0.13 \\
\hline Tennis racquets & 0.05 & 0.03 & 0.15 & 0.03 & 0.16 & 0.05 & 0.08 & 0.11 \\
\hline Printers & 0.07 & 0.06 & 0.07 & 0.03 & 0.06 & 0.03 & 0.05 & 0.10 \\
\hline CDs & 0.05 & 0.04 & 0.02 & 0.04 & 0.09 & 0.06 & 0.05 & 0.10 \\
\hline Toys & 0.06 & 0.16 & 0.29 & 0.07 & 0.45 & 0.14 & 0.20 & 0.24 \\
\hline Perfumes & 0.06 & 0.05 & 0.08 & 0.12 & 0.08 & 0.08 & 0.08 & 0.10 \\
\hline Clothes & 0.07 & 0.05 & 0.21 & 0.08 & 0.12 & 0.07 & 0.10 & 0.15 \\
\hline Calculators/organisers & 0.18 & 0.09 & 0.44 & 0.08 & 0.17 & 0.40 & 0.23 & 0.27 \\
\hline Watches & 0.10 & 0.25 & 0.27 & 0.24 & 0.38 & 0.24 & 0.25 & 0.38 \\
\hline Average & 0.08 & 0.08 & 0.16 & 0.08 & 0.16 & 0.12 & 0.11 & 0.17 \\
\hline
\end{tabular}

1. Coefficient of variation.

2. Arithmetic average of columns 1 to 6 . Only the countries with more than two cities are included in columns 1 to 6 .

3. Includes 11 countries (Austria, Belgium, France, Germany, Italy, Luxembourg, Netherlands, Portugal, Spain,

Switzerland and United Kingdom) and 39 cities.

Source: Test Achat (Belgian Consumer Organisation) and OECD.

Table 4. Price ratios and exchange rates

\begin{tabular}{|c|c|c|c|c|c|c|c|c|c|c|}
\hline & Austria & Belgium & Switzerland & Spain & France & $\begin{array}{r}\text { United } \\
\text { Kingdom }\end{array}$ & \multicolumn{2}{|c|}{ Italy Luxembourg } & Netherlands & Portugal \\
\hline & \multicolumn{10}{|c|}{ Price ratios } \\
\hline Germany & 6.98 & 20.56 & 1.01 & 78.46 & 3.48 & 0.361 & 928.2 & 20.29 & 1.14 & 93.52 \\
\hline Austria & .. & 2.94 & 0.14 & 11.23 & 0.50 & 0.052 & 132.9 & 2.90 & 0.16 & 13.39 \\
\hline Belgium & .. & .. & 0.05 & 3.82 & 0.17 & 0.018 & 45.1 & 0.99 & 0.06 & 4.55 \\
\hline Switzerland & .. & .. & .. & 77.74 & 3.45 & 0.358 & 919.8 & 20.10 & 1.13 & 92.67 \\
\hline Spain & .. & .. & .. & .. & 0.04 & 0.005 & 11.8 & 0.26 & 0.01 & 1.19 \\
\hline France & .. & .. & .. &.. & .. & 0.104 & 266.7 & 5.83 & 0.33 & 26.87 \\
\hline United Kingdom & .. & .. & .. &.. & .. & .. & 2570.1 & 56.17 & 3.16 & 258.93 \\
\hline Italy & .. & .. & .. &.. & .. & .. & .. & 0.02 & 0.00 & 0.10 \\
\hline Luxembourg & .. & .. & .. &.. & .. & .. & .. & .. & 0.06 & 4.61 \\
\hline \multirow[t]{2}{*}{ Netherlands } & .. & .. &.. &.. & .. & .. & .. & .. & .. & 81.82 \\
\hline & \multicolumn{10}{|c|}{ Exchange rates } \\
\hline Germany & 7.03 & 20.65 & 0.83 & 84.90 & 3.35 & 0.338 & 984.8 & 20.65 & 1.13 & 102.35 \\
\hline Austria & .. & 2.94 & 0.12 & 12.07 & 0.48 & 0.048 & 140.0 & 2.94 & 0.16 & 14.55 \\
\hline Belgium & .. & .. & 0.04 & 4.11 & 0.16 & 0.016 & 47.7 & 1.00 & 0.05 & 4.96 \\
\hline Switzerland & .. & .. & .. & 101.78 & 4.02 & 0.405 & 1180.5 & 24.75 & 1.35 & 122.69 \\
\hline Spain & .. & .. & .. &.. & 0.04 & 0.004 & 11.6 & 0.24 & 0.01 & 1.21 \\
\hline France & .. & .. & .. & .. & .. & 0.101 & 293.7 & 6.16 & 0.34 & 30.52 \\
\hline United Kingdom & .. & .. & .. & .. & .. & .. & 2912.1 & 61.06 & 3.33 & 302.65 \\
\hline Italy & .. & .. & .. &.. & .. & .. & .. & 0.02 & 0.00 & 0.10 \\
\hline Luxembourg & .. & .. & .. &.. & .. & .. & .. & .. & 0.05 & 4.96 \\
\hline Netherlands & .. & .. &.. & .. & .. & .. & .. & .. & .. & 90.75 \\
\hline
\end{tabular}

Source: OECD. 
Figure 1. Average commodity prices (1)

Percentage deviation from the mean

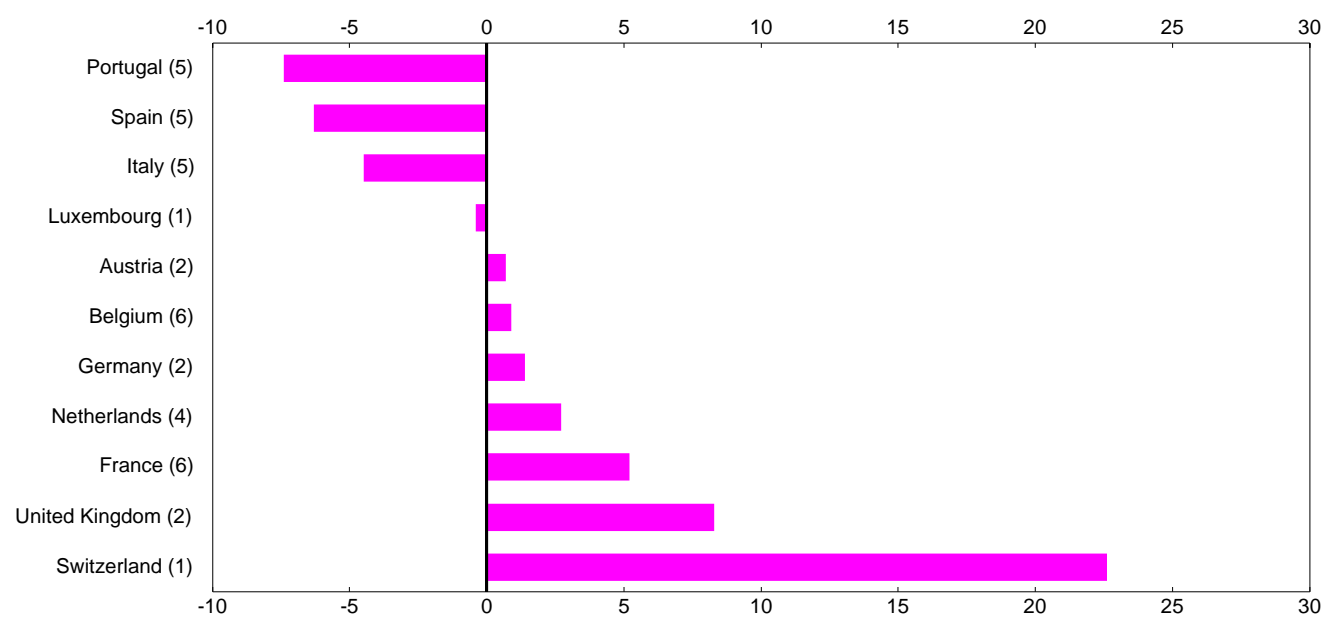

1. Data in brackets are the number of cities.

Source: Test Achat (Belgian Consumer Organisation) and OECD.

Table 5. Individual and pooled regression: common border effect

\begin{tabular}{lccccc}
\hline & \multicolumn{2}{c}{ Distance } & \multicolumn{2}{c}{ Border $^{2}$} & $\overline{\mathrm{R}}^{2}$ \\
& Parameter & P-value & Parameter & P-value $^{1}$ & \\
\cline { 2 - 5 } Car radios & -0.005 & $(0.17)$ & 0.030 & $(0.00)$ & 0.87 \\
Walkman/Portable CD players & -0.002 & $(0.66)$ & 0.012 & $(0.27)$ & 0.66 \\
Headphones & 0.009 & $(0.34)$ & -0.023 & $(0.37)$ & 0.73 \\
Hi-fi systems & 0.025 & $(0.00)$ & -0.001 & $(0.87)$ & 0.91 \\
Radio-cassette/CD players & -0.007 & $(0.18)$ & 0.021 & $(0.11)$ & 0.48 \\
Video cameras & -0.000 & $(0.99)$ & 0.017 & $(0.11)$ & 0.84 \\
Video tapes & -0.015 & $(0.06)$ & 0.177 & $(0.00)$ & 0.41 \\
Video recorders & 0.001 & $(0.81)$ & 0.015 & $(0.01)$ & 0.51 \\
Irons & 0.015 & $(0.00)$ & 0.038 & $(0.00)$ & 0.57 \\
Food mixers & 0.071 & $(0.00)$ & 0.041 & $(0.04)$ & 0.59 \\
Electric razors & 0.004 & $(0.26)$ & 0.035 & $(0.00)$ & 0.77 \\
Sport shoes & 0.018 & $(0.00)$ & 0.022 & $(0.03)$ & 0.64 \\
Tennis racquets & -0.004 & $(0.36)$ & 0.042 & $(0.00)$ & 0.48 \\
Printers & -0.002 & $(0.61)$ & 0.033 & $(0.00)$ & 0.56 \\
CDs & 0.005 & $(0.13)$ & 0.032 & $(0.00)$ & 0.52 \\
Toys & 0.018 & $(0.00)$ & -0.007 & $(0.63)$ & 0.95 \\
Perfumes & -0.007 & $(0.02)$ & 0.029 & $(0.00)$ & 0.46 \\
Clothes & 0.007 & $(0.17)$ & 0.035 & $(0.02)$ & 0.32 \\
Calculators/organisers & -0.007 & $(0.46)$ & 0.075 & $(0.00)$ & 0.87 \\
Watches & 0.080 & $(0.00)$ & 0.172 & $(0.00)$ & 0.49 \\
Pooled estimates & $\mathbf{0 . 0 1 0}$ & $\mathbf{0 . 0 0 )}$ & $\mathbf{0 . 0 4 0}$ & $\mathbf{( 0 . 0 0 )}$ & $\mathbf{0 . 2 9}$ \\
\hline
\end{tabular}

1. Indicates the confidence level at which parameters are significant. For example, a p-value of 0.01 indicates that a variable is significant at the 1 per cent level and values above 0.10 are not significant at the conventional 10 per cent confidence level.

Source: OECD. 
13. In order to assess the significance of the border effect separately from the influence of other factors on international price dispersion, econometric analysis is conducted on the basis of the following equation:

$$
\left|\ln \left(\mathrm{p}_{\mathrm{i}} / \mathrm{p}_{\mathrm{j}}\right)\right|=\sum_{\mathrm{m}=1}^{39} \alpha_{\mathrm{m}} \mathrm{DUMCITY}_{\mathrm{m}}+\beta \cdot \ln \left(\mathrm{DIST}_{\mathrm{i}, \mathrm{j}}\right)+\delta \cdot \operatorname{BORDER}+\mathrm{u}(\mathrm{i}, \mathrm{j})
$$

where the endogenous variable is the absolute difference in the log price level of a particular good between cities $i$ and $j$, DUMCITY is a set of dummy variables for each city to control for city-specific characteristics or idiosyncratic measurement errors that may influence the price level, ${ }^{16}$ DIST is the driving distance in kilometres between cities $i$ and $j$, BORDER is a dummy variable taking the value of unity if two cities are in different countries and $u(i, j)$ is the error term.

14. The equation is first estimated for each goods category separately. The results reported in Table 5 show that after controlling for distance and city-specific characteristics, a significant border effect remains for 15 of the 20 categories. The strongest border effects are found in the cases of watches and videotapes. Even though it is of much smaller magnitude, it is nevertheless striking that a significant border effect is found in the case of CDs, arguably the most homogeneous and highly tradable good included in the sample. Somewhat surprisingly, a significant distance effect is only detected in 7 categories (including CDs, significant at the 13 per cent level). In order to obtain more efficient estimates, the information across all categories is stacked and a pooled regression is performed. ${ }^{17}$

15. When the information is pooled, both the distance and border coefficients come out significantly, although the estimated effect appears relatively modest. For instance, the first parameter indicates that a one hundred per cent increase in distance between two cities adds only one per cent to the price differential. ${ }^{18}$ The border coefficient is more substantial. Given an average price differential in the whole sample of about 20 per cent, it suggests that about one-quarter of this differential is due to the border.

16. In order to allow for the border effect to vary across country pairs, the border dummy is then split into 54 dummies, one for each possible pair of countries included in the sample. ${ }^{19}$ Given that bilateral exchange rates have evolved differently across country pairs, allowing for different border coefficients may shed some light on the influence of past currency fluctuations on cross-border price dispersion. To avoid over-fitting and near perfect collinearity, the regression with the 54 dummies is performed only on the pooled sample. The results suggest that the importance of the border effect can vary significantly depending on the country pair (Table 6). As one might have expected, the bilateral border dummies involving Switzerland systematically come out with the largest coefficient, consistent with the fact that this is the only country in the sample not belonging to the European Union. ${ }^{20}$ The average border coefficient for the United Kingdom is the second largest, though it is substantially smaller than in the case of

16. For example, the dummy for city $\mathrm{X}$ has a unit value every time that city is involved in a price differential observation.

17. Individual dummies for each category are added to control for good-specific effects.

18. The average distance between city pairs in the whole sample is around 1200 kilometres. This is about twice the average distance observed between city pairs within countries.

19. The 54 border dummies are in addition to the 39 dummies for city characteristics and the 19 dummies for good-specific effects.

20. In future, this could change, in particular because of the package of sectoral agreements between Switzerland and the European Union. 
Switzerland. ${ }^{21}$ Given that Sterling appreciated sharply against most core EMS currencies in the years before the price survey was conducted, this may be seen as partly corroborating the evidence obtained by Engel and Rogers on the importance of the exchange rate channel. Moreover, given its geographic location, transportation costs in the case of the United Kingdom may be underestimated relative to other countries.

17. While 19 of the 54 border coefficients are not significant at the 10 per cent confidence level, Switzerland and the United Kingdom are the only two countries whose bilateral border coefficients are all significant. At the other end, Austria is the only country with no border parameters significant except for those against Switzerland and the United Kingdom. Somewhat surprisingly, Portugal is found to have the smallest and least significant border effect, preceded by Austria and Spain. In the case of Portugal, and to a lesser extent, Spain, this is consistent with the results reported in Table 3 showing that price dispersion is not much smaller within the country than cross-border. As an indirect test of the influence of exchange rate fluctuations on price dispersion, two alternative regressions were performed with the core-ERM members (Germany, France, the Netherlands, Belgium, Austria and Luxembourg) treated as a single country (Core-ERM). Portugal and Spain were also grouped together in a distinct group (SOUTH) given the small variations in their bilateral exchange rate in the years preceding EMU.

18. The results from these tests are reported in Table 7, which also include the results from the original pooled regression to facilitate comparison. In a first alternative specification, a second border dummy taking a unit value for every city pair involving two core-ERM countries and the SOUTH group (GROUPS) is added to the original regression. ${ }^{22}$ The negative parameter obtained confirms the smaller border effect when two cities from core-ERM countries and the SOUTH group are involved in the price comparison ( 0.032 compared to 0.055 for other countries). Note that this could reflect either the stability of exchange rates prior to 1998 and/or the deeper degree of market integration achieved between these countries. In an alternative specification, the border coefficients are introduced for each of the bilateral borders between the reduced groups of "countries". The regrouping of countries under Core-ERM and SOUTH allows for a reduction in the total number of bilateral borders from 55 to 10. The results show that all the border coefficients are significant albeit relatively small in the case of Core-ERM-SOUTH and SOUTH-Italy. A final test was conducted to see whether adjacent borders have a smaller effect on price differentials compared to non-adjacent borders. The results from this regression show that after controlling for distance, sharing a common border with a neighbour country does not significantly reduce the border effect.

21. As the sample includes only one city located in each of Switzerland and Luxembourg, the city-specific dummies for the two respective cities as well as the bilateral dummy for this country pair were not included in the regression. As a result, the estimated border effect for both countries is probably over-estimated because it also reflects some idiosyncratic factors not controlled for. Even so, the large difference in the average border effect between the two countries suggests that Switzerland would still have the largest border effect even after controlling for city-specific factors.

22. For example the dummy takes a value of one for a price differential involving a French and a Belgian city but zero in the case of two French or two Belgian cities as well as in the case of a city from a core-ERM versus one in a non-core-ERM country. 
Table 6. Pooled regression: individual border effects

\begin{tabular}{|c|c|c|}
\hline & Parameters & P-values ${ }^{1}$ \\
\hline \multicolumn{3}{|c|}{ Switzerland } \\
\hline Belgium & 0.279 & 0.00 \\
\hline Netherlands & 0.268 & 0.00 \\
\hline Germany & 0.263 & 0.00 \\
\hline France & 0.245 & 0.00 \\
\hline Italy & 0.239 & 0.00 \\
\hline Austria & 0.220 & 0.00 \\
\hline Spain & 0.218 & 0.00 \\
\hline Portugal & 0.196 & 0.00 \\
\hline United Kingdom & 0.194 & 0.00 \\
\hline Average & 0.236 & \\
\hline \multicolumn{3}{|c|}{ United Kingdom } \\
\hline Switzerland & 0.194 & 0.00 \\
\hline Luxembourg & 0.150 & 0.00 \\
\hline Spain & 0.085 & 0.01 \\
\hline Belgium & 0.082 & 0.01 \\
\hline Germany & 0.079 & 0.06 \\
\hline Austria & 0.074 & 0.08 \\
\hline Portugal & 0.071 & 0.03 \\
\hline France & 0.069 & 0.02 \\
\hline Italy & 0.063 & 0.05 \\
\hline Netherlands & 0.062 & 0.06 \\
\hline Average & 0.093 & \\
\hline \multicolumn{3}{|c|}{ Luxembourg } \\
\hline United Kingdom & 0.150 & 0.00 \\
\hline Italy & 0.097 & 0.00 \\
\hline Spain & 0.083 & 0.00 \\
\hline France & 0.078 & 0.00 \\
\hline Netherlands & 0.072 & 0.01 \\
\hline Portugal & 0.057 & 0.03 \\
\hline Belgium & 0.045 & 0.03 \\
\hline Austria & 0.046 & 0.26 \\
\hline Germany & 0.036 & 0.35 \\
\hline Average & 0.073 & \\
\hline \multicolumn{3}{|c|}{ Italy } \\
\hline Switzerland & 0.239 & 0.00 \\
\hline Luxembourg & 0.097 & 0.00 \\
\hline Germany & 0.073 & 0.01 \\
\hline Belgium & 0.065 & 0.00 \\
\hline United Kingdom & 0.063 & 0.05 \\
\hline France & 0.062 & 0.00 \\
\hline Netherlands & 0.050 & 0.00 \\
\hline Austria & 0.030 & 0.28 \\
\hline Spain & 0.019 & 0.18 \\
\hline Portugal & 0.012 & 0.41 \\
\hline Average & 0.071 & \\
\hline
\end{tabular}


Table 6. Pooled regression: individual border effects (continued)

\begin{tabular}{|c|c|c|}
\hline & Parameters & P-values ${ }^{1}$ \\
\hline \multicolumn{3}{|c|}{ Germany } \\
\hline Switzerland & 0.263 & 0.00 \\
\hline United Kingdom & 0.079 & 0.06 \\
\hline Italy & 0.073 & 0.01 \\
\hline Spain & 0.050 & 0.07 \\
\hline France & 0.048 & 0.07 \\
\hline Netherlands & 0.043 & 0.13 \\
\hline Luxembourg & 0.036 & 0.35 \\
\hline Belgium & 0.028 & 0.29 \\
\hline Austria & 0.027 & 0.49 \\
\hline Portugal & 0.021 & 0.44 \\
\hline Average & 0.067 & \\
\hline \multicolumn{3}{|c|}{ Belgium } \\
\hline Switzerland & 0.279 & 0.00 \\
\hline United Kingdom & 0.082 & 0.01 \\
\hline Italy & 0.065 & 0.00 \\
\hline France & 0.049 & 0.00 \\
\hline Luxembourg & 0.045 & 0.03 \\
\hline Spain & 0.039 & 0.00 \\
\hline Netherlands & 0.038 & 0.01 \\
\hline Germany & 0.028 & 0.29 \\
\hline Austria & 0.025 & 0.35 \\
\hline Portugal & 0.007 & 0.62 \\
\hline Average & 0.066 & \\
\hline \multicolumn{3}{|c|}{ France } \\
\hline Switzerland & 0.245 & 0.00 \\
\hline Luxembourg & 0.078 & 0.00 \\
\hline United Kingdom & 0.069 & 0.02 \\
\hline Italy & 0.062 & 0.00 \\
\hline Belgium & 0.049 & 0.00 \\
\hline Germany & 0.048 & 0.07 \\
\hline Spain & 0.040 & 0.00 \\
\hline Portugal & 0.026 & 0.06 \\
\hline Netherlands & 0.018 & 0.22 \\
\hline Austria & 0.016 & 0.55 \\
\hline Average & 0.065 & \\
\hline \multicolumn{3}{|c|}{ Netherlands } \\
\hline Switzerland & 0.268 & 0.00 \\
\hline Luxembourg & 0.072 & 0.01 \\
\hline United Kingdom & 0.062 & 0.06 \\
\hline Italy & 0.050 & 0.00 \\
\hline Germany & 0.043 & 0.13 \\
\hline Austria & 0.043 & 0.15 \\
\hline Belgium & 0.038 & 0.01 \\
\hline Spain & 0.021 & 0.20 \\
\hline France & 0.018 & 0.22 \\
\hline Portugal & 0.006 & 0.74 \\
\hline Average & 0.062 & \\
\hline
\end{tabular}


Table 6. Pooled regression: individual border effects (ended)

\begin{tabular}{|c|c|c|}
\hline & Parameters & P-values ${ }^{1}$ \\
\hline \multicolumn{3}{|c|}{ Spain } \\
\hline Switzerland & 0.218 & 0.00 \\
\hline United Kingdom & 0.085 & 0.01 \\
\hline Luxembourg & 0.083 & 0.00 \\
\hline Germany & 0.050 & 0.07 \\
\hline France & 0.040 & 0.00 \\
\hline Belgium & 0.039 & 0.00 \\
\hline Austria & 0.023 & 0.41 \\
\hline Netherlands & 0.021 & 0.20 \\
\hline Italy & 0.019 & 0.18 \\
\hline Portugal & 0.009 & 0.50 \\
\hline Average & 0.059 & \\
\hline \multicolumn{3}{|c|}{ Austria } \\
\hline Switzerland & 0.220 & 0.00 \\
\hline United Kingdom & 0.074 & 0.08 \\
\hline Luxembourg & 0.046 & 0.26 \\
\hline Netherlands & 0.043 & 0.15 \\
\hline Italy & 0.030 & 0.28 \\
\hline Germany & 0.027 & 0.49 \\
\hline Portugal & 0.027 & 0.34 \\
\hline Belgium & 0.025 & 0.35 \\
\hline Spain & 0.023 & 0.41 \\
\hline France & 0.016 & 0.55 \\
\hline Average & 0.053 & \\
\hline \multicolumn{3}{|c|}{ Portugal } \\
\hline Switzerland & 0.196 & 0.00 \\
\hline United Kingdom & 0.071 & 0.03 \\
\hline Luxembourg & 0.057 & 0.03 \\
\hline Austria & 0.027 & 0.34 \\
\hline France & 0.026 & 0.06 \\
\hline Germany & 0.021 & 0.44 \\
\hline Italy & 0.012 & 0.41 \\
\hline Spain & 0.009 & 0.50 \\
\hline Belgium & 0.007 & 0.62 \\
\hline Netherlands & 0.006 & 0.74 \\
\hline Average & 0.043 & \\
\hline Average of all borders & 0.079 & \\
\hline $\begin{array}{l}\text { Average excluding } \\
\text { Switzerland and } \\
\text { Luxembourg }\end{array}$ & 0.045 & \\
\hline Pooled distance & 0.015 & 0.00 \\
\hline
\end{tabular}

1. Indicates the confidence level at which parameters are significant. For example, a p-value of 0.01 indicates that a variable is significant at the 1 per cent level and values above 0.10 are not significant at the conventional 10 per cent confidence level.

Source : OECD. 
Table 7. Tests of alternative border specifications

\begin{tabular}{|c|c|c|}
\hline & Parameters & P-values ${ }^{1}$ \\
\hline \multicolumn{3}{|c|}{$\begin{array}{l}\text { Specification 1: Original regression with a common } \\
\text { border effect }\end{array}$} \\
\hline Distance & 0.010 & 0.00 \\
\hline Border & 0.040 & 0.00 \\
\hline \multicolumn{3}{|c|}{$\begin{array}{l}\text { Specification 2: Test of distinct border effect for sub- } \\
\text { groups of countries }\end{array}$} \\
\hline Distance & 0.004 & 0.22 \\
\hline Border & 0.055 & 0.00 \\
\hline Border-GROUPS $^{2}$ & -0.023 & 0.00 \\
\hline \multicolumn{3}{|c|}{$\begin{array}{l}\text { Specification 3: Bilateral border effects over the smaller } \\
\text { set of "countries" }\end{array}$} \\
\hline Distance & 0.007 & 0.02 \\
\hline \multicolumn{3}{|l|}{ Borders: } \\
\hline Core-ERM - SOUTH & 0.021 & 0.00 \\
\hline Core-ERM - Switzerland & 0.278 & 0.00 \\
\hline Core-ERM - United Kingdom & 0.068 & 0.01 \\
\hline Core-ERM - Italy & 0.052 & 0.00 \\
\hline SOUTH - Switzerland & 0.241 & 0.00 \\
\hline SOUTH - United Kingdom & 0.092 & 0.00 \\
\hline SOUTH - Italy & 0.023 & 0.03 \\
\hline Switzerland - United Kingdom & 0.233 & 0.00 \\
\hline Switzerland - Italy & 0.263 & 0.00 \\
\hline United Kingdom - Italy & 0.077 & 0.01 \\
\hline Average of all borders & 0.135 & \\
\hline Average of Core-ERM borders & 0.105 & \\
\hline \multicolumn{3}{|c|}{$\begin{array}{l}\text { Specification } 4 \text { : Test of distinct border effects for } \\
\text { countries with adiacent borders }{ }^{3}\end{array}$} \\
\hline Distance & 0.009 & 0.00 \\
\hline Border & 0.044 & 0.00 \\
\hline Adjacent borders & -0.005 & 0.33 \\
\hline
\end{tabular}

1. Indicates the confidence level at which parameters are significant. For example, a p-value of 0.01 indicates that a variable is significant at the 1 per cent level and values above 0.10 are not significant at the conventional 10 per cent confidence level.

2. The dummy BORDER-GROUPS takes a value of one when two cross-border cities belong to either the Core-ERM or SOUTH country groups. The groups are Core-ERM: Austria, Belgium, France, Germany, Luxembourg and Netherlands and SOUTH: Spain and Portugal.

3. The dummy ADJACENT takes a value of one when cross-border cities belong to countries sharing a common border.

Source: OECD. 


\section{Conclusions}

19. This paper has estimated the significance of the border effect within Europe using price data for specific categories of manufactured goods collected in a large number of cities across 11 countries. Overall, the results indicate that, even on the basis of comparable, highly tradable goods and after controlling for distance and city-specific characteristics, the dispersion of prices in the European Union remains on average around 20 to 25 per cent higher across borders than within countries. In some cases (e.g. the United Kingdom), part of the dispersion may reflect large currency movements in the months preceding the conduct of the survey. However, significant (bilateral) border effects are also found in the case of other countries, such as Germany, Belgium and the Netherlands, which had their bilateral parities fixed for years before the introduction of the euro. The largest border effects are systematically found in the case of Switzerland, followed by the United Kingdom, the only two countries in the sample that are not members of the euro area.

20. The average border effect estimated in this paper is five to six times smaller than the one obtained in a previous study based on CPI data collected in European cities. This is consistent with the fact that CPIs reflect a large proportion of non-traded goods and services. Even though this is not directly comparable, the border effect estimated in this paper is also significantly smaller than that observed between Canadian and US cities, suggesting that cross-country dispersion appears to be smaller in Europe than in the case of the United States and Canada. The view that cross-border market integration is more advanced in the European Union than it is typically across the other OECD countries is corroborated by alternative evidence based on business cycle synchronisation as well as consumption and output growth correlations. However, the same indicators reveal that integration in the European Union still has quite some way to go before being comparable to what is found within countries.

21. Finally, estimates of border effects based on price data are generally smaller than those derived from trade flow data, especially in the case of Europe. This is consistent with the fact that lowering administrative and other policy barriers to trade raises the contestability of home markets, which may have an impact on prices even if trade flows have not yet changed significantly. In this respect, the comparison of prices may provide a better indication of how far integration has proceeded. 


\section{Bibliography}

Anderson, M. A. and S. L. S. Smith (1999),

"Do National Borders Really Matter? Canada-US Regional Trade Reconsidered", Review of International Economics, 7(2).

Blanchard, O. (1991),

"Price Asynchronization and Price-Level Inertia", in: G. Mankiw and D. Romer (eds.), New

Keynesian Economics, Vol. 1, MIT Press.

Clark, T. and K. Shin (1998),

"The Sources of Fluctuations Within and Across Countries", Federal Reserve Bank of Kansas City Research Working Paper, No. 98-04.

Crucini, M. and G. Hess (2000),

"International and Intranational Risk Sharing", in: G. Hess and E. van Wincoop (eds.), Intranational Macroeconomics, Cambridge University Press.

Doyle, L. (2000),

“DKBR Pricing Survey 2000”, Dresdner Kleinwort Benson Resarch, 22 September.

EC (2000),

"Market Integration and Differences in Price Levels", Study 4, in: The EU Economy: 2000 Review, European Economy No. 71.

Engel, C. and J. H. Rogers (1996),

"How Wide is the Border?", American Economic Review, Vol. 86, No. 5.

Engel, C. and J. H. Rogers (2000a),

"Deviations from the Law of One Price: Sources and Welfare Costs", Board of Governors of the Federal Reserve System, International Finance Discussion Paper, No. 644.

Engel, C. and J. H. Rogers (2000b),

"Relative Price Volatility: What Role does the Border Play?", in: G. Hess and E. van Wincoop (eds.), Intranational Macroeconomics, Cambridge University Press.

Forni, M. and L. Reichlin (2001),

"Federal Policies and Local Economies: Europe and the US", European Economic Review, No. 45.

Goldberg, P. and F. Verboven (1998),

"The evolution of Price Dispersion in the European Car Market", CEPR Discussion Paper, No. 2029.

Haskel, J. and H. Wolf (2001),

"The Law of One Price - A Case Study", NBER Working Paper Series, No. 8112. 
ECO/WKP(2001)30

Helliwell, J. (1996),

“Do National Borders Matter for Quebec?", Canadian Journal of Economics, Vol. 29, No. 3.

Helliwell, J. (1998),

How Much Do National Borders Matter?, Brookings Institution Press, Washington D.C.

Hess, G. and E. van Wincoop (eds.) (2000),

Intranational Macroeconomics, Cambridge University Press.

Lewis, K. (1999),

"Trying to Explain Home Bias in Equities and Consumption", Journal of Economic Literature, Vol. 31, No. 2.

McCallum, J. (1995),

National Borders Matter: Canada-US Regional Trade Patterns", American Economic Review, Vol. 85, No. 3.

Nitsch, V. (2000),

"National Borders and International Trade: Evidence from the European Union", Canadian Journal of Economics, Vol. 33, No. 4.

OECD (1999),

EMU: Facts, Challenges and Policies, Paris.

OECD $(2000 a)$

EMU: One Year On, Paris.

$\operatorname{OECD}(2000 b)$,

OECD Economic Outlook 68, Paris.

$\operatorname{OECD}(2001)$

Economic Survey of the Euro Area, Paris.

Parsley, D. C. and S.-J. Wei (2000),

"Explaining the Border Effect: The Role of Exchange Rate Variability, Shipping Costs and

Geography", NBER Working Paper Series, No. 7836.

Rogers, J. H. and H. P. Smith (2001),

"Border Effects within the NAFTA Countries", Board of Governors of the Federal Reserve System, International Finance Discussion Papers, No. 698

Van Wincoop, E. (2000),

"International versus Intranational Saving-Investment Co-movements", in: Hess, G. and E. van Wincoop (eds.), Intranational Macroeconomics, Cambridge University Press.

Wei, S.-J. (1996),

"Intranational versus International Trade: How Stubborn are Nations in Global Integration?", NBER Working Paper Series, No. 5531.

Wolf, H. (2000),

“(Why) Do Borders Matter for Trade?”, in: G. Hess and E. van Wincoop (eds.), Intranational Macroeconomics, Cambridge University Press. 


\section{ECONOMICS DEPARTMENT}

\section{WORKING PAPERS}

303. Surveillance of Tax Policies: a Synthesis of Findings in Economic Surveys (July 2001) Paul van den Noord and Christopher Heady

302. Reforming the Tax System in Portugal

(Jyly 2001) Chiara Bronchi, José C. Gomes-Santos

301. Tax Systems in European Union Countries

(June 2001) Isabelle Joumard

300. Encouraging Environmentally Sustainable Growth in Belgium (June 2001) Paul O’Brien, David Carey, Jens Høj, Andreas Woergoetter

299. Encouraging Environmentally Sustainable Growth in Poland (June 2001) Grzegorz Peszko, Patrick Lenain

298. Tracking the Euro

(June 2001) Vincent Koen, Laurence Boone, Alain de Serres, Nicola Fuchs

297. Firm Dynamics and Productivity Growth: A Review of Micro-evidence from OECD Countries (June 2001) Sanghoon Ahn

296. How should Norway Respond to Ageing?

(May 2001) Pablo Antolín and Wim Suyker

295. How will Ageing Affect Finland?

(May 2001) Pablo Antolín, Howard Oxley and Wim Suyker

294. Sectoral Regulatory Reforms in Italy: Framework and Implications (May 2001) Alessandro Goglio

293. Encouraging Environmentally Sustainable Growth: Experience in OECD Countries (May 2001) Paul O'Brien and Ann Vourc'h

292. Increasing Simplicity, Neutrality and Sustainability: A Basis for Tax Reform in Iceland (May 2001) Richard Herd and Thorsteinn Thorgeirsson

291. Options for Reforming the Tax System in Greece (April 2001) Chiara Bronchi

290. Encouraging Environmentally Sustainable Growth in Canada (March 2001) Ann Vourc'h

289. Encouraging Environmentally Sustainable Growth in Sweden (March 2001) Deborah Roseveare

288. Public Spending in Mexico: How to Enhance its Effectiveness (March 2001) Bénédicte Larre and Marcos Bonturi

287. Regulation in Services: OECD Patterns and Economic Implications (February 2001) Giuseppe Nicoletti 
ECO/WKP(2001)30

286. A Small Global Forecasting Model

(February 2001) David Rae and David Turner

285. Managing Public Expenditure: Some Emerging Policy Issues and a Framework for Analysis (February 2001) Paul Atkinson and Paul van den Noord

284. Trends in Immigration and Economic Consequences

(February 2001) Jonathan Coppel, Jean-Christophe Dumont and Ignazio Visco

283. Economic Growth: The Role of Policies and Institutions.

Panel Data Evidence from OECD Countries

(January 2001) Andrea Bassanini, Stefano Scarpetta and Philip Hemmings

282. Does Human Capital Matter for Growth in OECD Countries? Evidence from Pooled Mean-Group Estimates (January 2001) Andrea Bassanini and Stefano Scarpetta

281. The Tax System in New Zealand: An Appraisal and Options for Change (January 2001) Thomas Dalsgaard

280. Contributions of Financial Systems to Growth in OECD Countries (January 2001) Michael Leahy, Sebastian Schich, Gert Wehinger, Florian Pelgrin and Thorsteinn Thorgeirsson

279. House Prices and Economic Activity

(January 2001) Nathalie Girouard and Sveinbjörn Blöndal

278. Encouraging Environmentally Sustainable Growth in the United States (January 2001) Paul O’Brien

277. Encouraging Environmentally Sustainable Growth in Denmark (January 2001) Paul O’Brien and Jens Høj

276. Making Growth more Environmentally Sustainable in Germany (January 2001) Grant Kirkpatrick, Gernot Klepper and Robert Price

275. Central Control of Regional Budgets : Theory with Applications to Russia (January 2001) John M. Litwack

274. A Post-Mortem on Economic Outlook Projections (December 2000) Vassiliki Koutsogeorgopoulou

273. Fixed Cost, Imperfect Competition and Bias in Technology Measurement: Japan and the United States (December 2000) Kiyohiko G. Nishimura and Masato Shirai

272. Entry, Exit, and Aggregate Productivity Growth: Micro Evidence on Korean Manufacturing (December 2000) Chin-Hee Hahn

271. The Tax System in Korea: More Fairness and Less Complexity Required (December 2000) Thomas Dalsgaard

270. A Multi-Gas Assessment of the Kyoto Protocol (October 2000) Jean-Marc Burniaux

269. The Changing Health System in France (October 2000) Yukata Imai, Stéphane Jacobzone and Patrick Lenain 